\title{
Az örökletes emlőrák szürésének, megelőzésének és kezelésének új nemzetközi irányvonalai - hazai vonatkozásokkal
}

\author{
Romics László dr. ${ }^{1}$ - Kocsis Judit dr. ${ }^{2}$ \\ Ormándi Katalin dr. ${ }^{3}$. Molnár Béla Ákos dr. ${ }^{4}$ \\ ${ }^{1}$ New Victoria Hospital és Queen Elizabeth University Hospital, Glasgow, Egyesült Királyság \\ ${ }^{2}$ Debreceni Egyetem, Általános Orvostudományi Kar, Klinikai Központ, Onkológiai Intézet, Debrecen \\ ${ }^{3}$ Szegedi Tudományegyetem, Általános Orvostudományi Kar, Radiológiai Klinika, \\ Diagnoscan Magyarország Kft., Szeged \\ ${ }^{4}$ Semmelweis Egyetem, Általános Orvostudományi Kar, I. Sebészeti Klinika, Budapest
}

\begin{abstract}
Bevezetés: Az örökletes emlőrák szứrése, megelőzése és kezelése összetett, multidiszciplináris feladat. A familiáris emlőrák ellátására új ajánlásokat publikáltak az Egyesült Királyságban. Célkitüzés: A szerzők az angliai és skóciai ajánlásokat, azok evidenciáit és az ezzel kapcsolatos magyarországi helyzetet foglalják össze. Módszer: A National Institute for Health and Care Excellence és a Familial Breast Cancer Report (NHS Scotland) ajánlásai és a hazai gyakorlat elemzése. Eredmények: Az új ajánlások jelentősen növelik a genetikai tesztek és az ezzel kapcsolatos genetikai tanácsadások számát. Az új ajánlások alapján lényegesen több mágneses rezonanciás vizsgálat javasolt az emlőszứrésben. Az érintett egyéneknek közepes kockázattól felfelé kemoprevenció ajánlható. Az örökletes emlorrák szisztémás kezelésében új utakat nyithatnak az egyes platinaszármazékokkal és a poli-ADP-ribóz polimeráz inhibitorokkal végzett klinikai vizsgálatok. Az egészségügyi költségvetést számottevően megterhelhetik a jelentősen megnövekedett genetikai tesztvizsgálatok, a genetikai tanácsadások, az emlő mágneses rezonanciás vizsgálatai. Következtetések: A fenti ajánlások bizonyos területeken meg fogják változtatni a familiáris emlőrák ellátásának jelenlegi klinikai gyakorlatát. Orv. Hetil., 2016, 157(28), 1117-1125.
\end{abstract}

Kulcsszavak: emlőrák, örökletes, kezelés, szűrés, ajánlás

\section{Latest international guidelines for screening, prevention and treatment of familial breast cancer - implications for the relevant practice in Hungary}

Introduction: Screening, prevention and treatment of familial breast cancer require a multidisciplinary approach. New guidelines were published in the United Kingdom for the management of familial breast cancer. Aim: The authors summarise these new guidelines and analyse the relevant practice in Hungary. Method: Relevant guidelines of the National Institute for Health and Care Excellence and Familial Breast Cancer Report (NHS Scotland) are described. Results: New guidelines will increase the number of genetic tests as well as genetic counselling. An increase in the number of breast magnetic resonance imaging is expected, too. Chemoprevention can be offered for individuals with medium risk and above. Promising trials are underway with platinum based chemotherapy and polyADP-ribose polimerase inhibitors for the systemic treatment of familial breast cancer. The increase in the number of genetic tests, counselling, and breast magnetic resonance imaging may have a significant impact on health care budget. Conclusions: These guidelines will change some aspects of the current management of familial breast cancer.

Keywords: breast cancer, familial, management, guideline

Romics, L., Kocsis, J., Ormándi, K., Molnár, B. Á. [Latest international guidelines for screening, prevention and treatment of familial breast cancer - implications for the relevant practice in Hungary]. Orv. Hetil., 2016, 157(28), $1117-1125$.

(Beérkezett: 2016. március 13.; elfogadva: 2016. április 19.) 


\section{Rövidítések}

ESMO = European Society of Medical Oncology; ESO = European Society of Oncology; $\mathrm{MMG}=$ mammogram; MRI = magnetic resonance imaging; NICE $=$ National Institute for Health and Care Excellence; OEP = Országos Egészségbiztosítási Pénztár; OOI = Országos Onkológiai Intézet; PARP = poli-ADP-ribóz polimeráz; SIGN = Scottish Intercollegiate Guidelines Network; TNBC = triple negative breast cancer; $\mathrm{UH}=$ ultrahang

A National Institute for Health and Care Excellence (NICE), amely Angliában és Walesben határozza meg a szakmai irányelveket, 164-es számmal publikálta az örökletes (familiáris) emlőrákra vonatkozó legújabb ajánlásait [1]. Ezt egy év múlva, 2014 nyarán követte ennek egyszerúsített, skóciai változata, amely azonban számos részletkérdésben eltér az eredeti NICE-ajánlásoktól [2]. Mindkét értekezés a legfrissebb és a lehető legmagasabb evidencia alapján közölt ajánlásokat a familiáris emlőrák genetikai és radiológiai szürésével és megelőzésével kapcsolatban. A fentieken kívül a szerzők áttekintik az örökletes emlőrák kezelésének legújabb lehetőségeit. A legújabb brit ajánlások tükrében a hazai állapotokat, lehetőségeket és problémákat is tárgyalják.

\section{Mikor kell az örökletes emlőrák kialakulásának veszélyére gondolni a családi anamnézis alapján az alapellátásban?}

Minden olyan egyént, akinél a családi anamnézis alapján örökletes emlőrák valószínúsíthető, az alapellátásból a szakirányú ellátás felé kell irányítani. Örökletes emlőrákot valószínúsít, ha valakinek az elsőfokú nőrokonánál az emlörákot 40 éves kora előtt diagnosztizáltak, vagy ha elsőfokú férfi rokon emlőrákját észlelték bármely életkorban. Szintén az örökletes emlőrákot valószínúsíti, ha elsőfokú rokonnál kétoldali emlőrák fordult elő, és az első emlőrákot 50 éves életkor alatt diagnosztizálták. Az örökletes emlőrák előfordulásának kockázata szintén nagyobb, ha két elsőfokú, illetve egy első- és egy másodfokú rokonnál bármely életkorban diagnosztizáltak emlő- rákot. Az örökletes emlőrák kialakulásának lehetőségét szintén növeli, ha első- és másodfokú rokonoknál bármely életkorban emlö- és ovariumcarcinoma együttesen fordult elő. Azokat az egyéneket, akiknek első- vagy másodfokú rokonánál három vagy több emlőrákot diagnosztizáltak, az alapellátásból a szakirányú ellátás felé kell utalni (1. táblázat). (Elsőfokú rokonnak számít a szülő, gyermek, testvér. Másodfokú rokon a nagyszülő, unoka, nagynéni, nagybácsi, elsőfokú unokatestvér és féltestvér.)

Genetikai szúrés alkalmával észlelt BRCAl-, BRCA2vagy TP53-mutáció esetén az egyént természetesen közvetlenül klinikai genetikushoz kell irányítani. A fenti génmutációk kimutatása automatikusan azt jelenti, hogy az adott egyén az örökletes emlőrák kialakulása szempontjából a nagyon magas kockázatú csoportba tartozik (1. táblázat).

Mindezeken kívül ajánlatos tanácsot kérni klinikai genetikustól, ha a családi anamnézisben az emlőrákon kívül kétoldali férfi emlőrák, ovariumcarcinoma, askenázi zsidó ősök esetében sarcoma, 45 évesnél fiatalabb rokonban diagnosztizált glioma, gyermekkori mellékvese corticalis carcinoma, halmozottan jelentkező malignus betegségek fiatalabb korban, vagy ha az apai ágon legalább két emlőrák együttes előfordulása ismert.

\section{Az örökletes emlőrák kialakulásának kockázata}

Az átlagpopulációban egy nő teljes életideje alatt (pontosabban 20 éves kortól mérve) az emlőrák kialakulásának valószínúsége $17 \%$ alatt van (1. táblázat). Ugyanez egy 40-50 év közötti nőnél 3\% vagy az alatti. A közepes kockázatú egyéneknél a valószínúség 17\% és $30 \%$ közé emelkedik az egész élettartamra számítva, míg a 40 és 50 év közöttieknél 3\% és 8\% közé. Az örökletes emlőrák kialakulásának valószínúsége magas kockázattal érintett nőknél ugyanakkor már 30\% felett van az élettartamot figyelembe véve, illetve $8 \%$ felett 40 és 50 év között. Magas rizikójú csoportba tartozik természetesen minden olyan egyén, akinél BRCA1-, BRCA2-, TP53-mutációt mutattak ki, vagy olyan ritkábban előforduló genetikai kórképeket, mint a Peutz-Jeghers-szindróma (STKIl-

1. táblázat |Az örökletes emlőrák kockázati csoportjai

\begin{tabular}{|c|c|c|c|c|}
\hline Kockázat & Alacsony & Közepes & Magas & Nagyon magas \\
\hline $\begin{array}{l}\text { Emlőcarcinoma } \\
\text { kialakulásának esélye (\%) }\end{array}$ & $\begin{array}{l}\leq 17 \% ; \\
10 \text { éves kockázat } \\
\text { 40. életévtól: } \\
3-8 \%\end{array}$ & $\begin{array}{l}\text { 17-30\%; } \\
10 \text { éves kockázat } \\
40 \text {. életévtől: } \\
\geq 8 \%\end{array}$ & $\geq 30 \%$ & $\begin{array}{l}10 \text { éves kockázat } \\
30 \text {. életévtől: } \geq 8 \% \text {; } \\
10 \text { éves kockázat } \\
40 \text {. életévtől: } \geq 20 \%\end{array}$ \\
\hline $\begin{array}{l}\text { Családi anamnézis / } \\
\text { génmutáció }\end{array}$ & Normálpopuláció & $\begin{array}{l}40 \text { év alatti elsőfokú rokon } \\
\text { emlörákkal vagy férfi } \\
\text { emlörák; legalább két } \\
\text { első- vagy másodfokú } \\
\text { rokon emlő- és/vagy } \\
\text { ovariumrákkal }\end{array}$ & $\begin{array}{l}\text { Egy egyénben emlő- és } \\
\text { ovariumrák együttes } \\
\text { előfordulása; BRCA1, } \\
\text { BRCA2 és TP53 } \\
\text { elófordulásának } \\
\text { valószínűsége } \geq 20 \%\end{array}$ & $\begin{array}{l}\text { Kimutatott BRCA1-, } \\
\text { BRCA2- vagy TP53- } \\
\text { mutáció, vagy ennek } \\
\text { valószínúsége } \geq 30 \%\end{array}$ \\
\hline
\end{tabular}


mutáció), Cowden-kór (PTEN) vagy familiáris diffúz gyomorcarcinoma (E-kadherin) (1. táblázat). Magyarországon az emlőrákok 7\%-a, a petefészekrákok 11\%-a, a férfi emlőrákok 33\%-a örökletes [3].

\section{A genetikai szürés időszerü kérdései}

Génmutáció valószínűségének eldöntésében a családi anamnézis vizsgálatán kívül speciális génkarrier valószínúségi számítások is fontos információt nyújtanak. A BOADICEA vagy a Manchester Scoring System használata ajánlott annak eldöntésében, hogy szükséges-e az egyént klinikai genetikushoz irányítani genetikai szűrővizsgálat elvégzése céljából [4].

Általában véve genetikai szűrővizsgálat elvégzése indokolt, ha a kombinált BRCAl/BRCA2 mutáció valószínưsége legalább 10\%, függetlenül attól, hogy az adott egyén anamnézisében szerepel-e korábbi emlő- vagy ovariumcarcinoma. A genetikai vizsgálat elvégzése akkor is indokolt, ha - személyes anamnézis hiányában - a családi anamnézisben szereplő egyének genetikai vizsgálata nem lehetséges. Ilyen esetekben a 10\%-os kombinált BRCA1/BRCA2 mutáció azt jelenti, hogy a családban $20 \%$ felett van a génmutáció valószínúsége.

Olyan betegeknél, akiknél emlőcarcinoma diagnózisa után közvetlenül indokolt a genetikai teszt elvégzése, ennek lehetőségét természetszerúleg biztosítani kell. Ugyanakkor, sok esetben a genetikai vizsgálat eredménye befolyásolhatja a sebészi kezelés kiválasztását, hiszen mastectomia, illetve ellenoldali rizikócsökkentő mastectomia elvégzése is indokolt lehet egy relatíve kis méretú, amúgy emlőmegtartó mütéttel eltávolítható carcinoma esetében [5]. A jelenleg folyó onkológiai vizsgálatok eredményétől függően lehetséges, hogy egy génmutáció jelenléte az adjuváns terápiát is befolyásolja [6]. A jövőben lehetőség nyílhat BRCAl/BRCA2/TP53 mutáció kimutatására az emlőrák diagnózisát követő 4 héten belül, az erre vonatkozó klinikai vizsgálatok folyamatban vannak $[7,8]$. A gyorsított genetikai diagnózis azonban nagy mennyiségű és jelentőségű további információ feldolgozását igényelheti a betegtől, amely nem feltétlenül felel meg minden betegnek, hiszen sokan alkatilag is nehezen küzdenek meg az emlőrák diagnózisával [9].

Magyarországon az Országos Onkológiai Intézet (OOI) Molekuláris Genetikai Osztályán az onkogenetikai kutatások a daganatos gének expressziójának szabályozására, a génexpressziós mintázat meghatározására és ennek terápiás célú befolyásolására fókuszálnak [10]. A munkacsoport úttörő szerepet játszott az örökletes emlőrákban kulcsfontosságú, BRCAl gén múködésének kimutatásában, többek között a gént érintő alternatív splicing szerepének és szabályozásának bemutatásában, illetve azok szövetspecifikus variánsainak leírásában [11, 12]. A Breast Cancer Linkage Consortium (BCLC) nevü európai kutatói hálózathoz társulva mutatták ki, hogy a BRCAl tumorszuppresszor gén, megjelölve a gén pontos kromoszomális helyét a BRCAl-régión belül, és ki- mutatva, hogy a családi halmozódású betegeknél az úgynevezett vad allél elvész, emiatt a mutáns allél hatása érvényesül [13]. Az emlőrák kialakulásáért felelős további genetikai variánsokat írtak le a genom több szakaszának vizsgálata során meghatározva azok kromoszomális helyét is [14].

Populációgenetikai és génkörnyezet-kölcsönhatási kutatások részeként a kelet- és közép-európai régió örökletes daganataiért felelős mutációkat publikálták, amely hét országot felölelő kelet- és közép-európai rákgenetikai hálózat keretein belül valósult meg $[3,15]$. Ezeknek a kutatásoknak köszönhetően a magyarországi daganatos megbetegedések genetikai hátteréről és azok genotípus-fenotípus összefüggéseiről részletes ismereteink vannak nemzetközi összehasonlításban is $[3,16,17]$.

$\mathrm{Az}$ onkogenomikai kutatások elterjedésével egyre pontosabb képet kaptunk a hazai örökletes emlö- és petefészekrákos megbetegedésekért felelős kóroki BRCAl és BRCA2-mutációk szerepéról, illetve a kelet- és középeurópai térségben előforduló populációspecifikus mutációk fenotípus-következményeiről $[15,18]$. Több ezer egyén adatait magába foglaló multicentrikus vizsgálatok alapján árnyaltan mutatták be a BRCA-mutációk által közvetített rákkockázat mértékét és genotípus-fenotípus összefüggéseket $[16,17]$.

A mindennapi gyakorlat kulcsfontosságú elemeként az OOI-ben kialakított multidiszciplináris munkacsoport Magyarországon és a régióban elsőként vezette be az örökletes emlő-, petefészekrákos családok részére a molekuláris genetikai vizsgálatokat, illetve a genetikai tanácsadást $[18,19]$. Ma már egyre több helyen válik elérhetővé a vizsgálat, csak Budapesten 14 helyen végeznek - többnyire csak néhány mutációra kiterjedő - BRCAtesztet [3]. Ezenkívül az OOI-ban hazai és nemzetközi (kutatási) pályázati támogatással a BRCA-mutációra negatív családokban az összes ismert hajlamosító génre végeznek vizsgálatot, illetve a BRCA-mutációra pozitív családokban/esetekben pedig az emlőrák kockázatát módosító új géneket szû́rnek. Mindezt nagyban elősegíti a nemzetközi viszonylatban is kiváló, nagyon rövid tesztelési idő ( 2 hét a vérvételtől számítva), amely kulcsfontosságú lehet a klinikai döntéshozatal szempontjából.

\section{Radiológiai szürés és utánkövetés}

A radiológiai szűrésre vonatkozó ajánlások eltérőek azoknál a közepes, magas és nagyon magas kockázatú egyéneknél, akiknek anamnézisében korábbi emlőcarcinoma diagnózisa nem szerepel (2. táblázat).

A közepes kockázatú egyének évenkénti mammográfiás szürése indokolt 40-49 év között, illetve 50 éves kor felett. Hasonlóképpen, évenkénti mammográfiás szűrővizsgálat elvégzése indokolt olyan 40-59 év közötti és 60 év feletti, magas kockázatú betegeknél, akiknél maximum 30\% annak az esélye, hogy BRCA- vagy TP53-mutációval rendelkeznek, illetve azokban az esetekben, ha a BRCA-mutációnak 30\%-nál több az esélye, de genetikai 
szürôvizsgálat még nem történt [20] (2. táblázat). Ez a skóciai ajánlásban úgy módosult, hogy az évenkénti mammográfiát a családban előfordult legfiatalabb, az emlőcarcinoma diagnózisánál 5 évvel korábban (de nem 35 év alatt) kell elkezdeni [2]. Kimutatott BRCA-mutáció esetén évenkénti mammográfia indokolt 40-69 év között, illetve a skóciai ajánlások szerint 70 év felett is. Évenkénti mammográfiás szűrővizsgálat nem indokolt 29. életév alatt, kimutatott TP53-mutáció esetén, illetve ha a TP53-mutáció esélye 30\% felett van, de génvizsgálat még nem történt (2. táblázat). A fenti mammográfiás szưrővizsgálatok elvégzése olyan centrumokban javasolt, ahol digitális mammográfiás vizsgálatot képesek végezni, és a szürőcentrumokhoz hasonlóan az eredményeket rendszeresen auditálják.

Évenkénti emlő MRI-s szűrővizsgálat indokolt olyan egyéneknél 30-49 év között, akiknél a BRCA-mutáció valószínúsége $30 \%$ felett van, de nem vettek még részt genetikai szűrővizsgálaton. Hasonlóképpen, évenkénti MRI indokolt ismert BRCA1- és BRCA2-mutációt hordozóknál 30-49 év között [21] (2. táblázat). Évenkénti emlő-MRI-t kell végezni olyan 20-49 év közötti egyéneknél, akiknél a TP53-mutáció valószínüsége 30\% felett van vagy kimutatott TP53-mutációval rendelkeznek. Évenkénti MRI-szűrés indokolt olyan egyéneknél 50-69 év között, akik BRCAl/BRCA2/TP53 hordozók vagy erre 30\%-nál nagyobb az esélyük, és mammográfiás vizsgálattal az emlőállomány olyan magas denzitású, hogy az jelentősen csökkenti a mammográfia szenzitivitását [22] (2. táblázat). Itt azonban meg kell jegyezni, hogy a nagy denzitású emlőállomány definíciója jelentősen eltér a különböző nemzetközi radiológiai társaságok ajánlásaiban, és ez nehezen objektivizálható. Míg az emlőállomány denzitása a kor előrehaladtával csökken, különösképpen menopauza után, hirtelen változás nem köthető egy adott életkorhoz. Egyénenként különböző, hogy mikor lesz a mammográfiás vizsgálat szenzitívebb és specifikusabb 50 év felett, mint az MRI. Az eddigi nemzetközi vizsgálatok egyike sem tudta igazolni az MRI prioritását a mammogrammal szemben 50 év feletti nőknél, a fenti kérdésben egyedi elbírálás szükséges lehet a megfelelő

2. táblázat $\mid$ Az örökletes emlőrák radiológiai szúrése életkor és a kockázati csoportok szerint

\begin{tabular}{l|lll}
\hline \multirow{2}{*}{ Életkor (év) } & \multicolumn{3}{|l}{ Emlőcarcinoma kialakulásának kockázata } \\
\cline { 2 - 4 } & Közepes & Magas & Nagyon magas \\
\hline $20-29$ & - & - & $\begin{array}{l}\text { MRI (TP53- } \\
\text { mutáció) }\end{array}$ \\
\hline $30-39$ & - & Esetleg MMG & $\begin{array}{l}\text { MRI és esetleg } \\
\text { MMG }\end{array}$ \\
\hline $40-49$ & MMG & MRI és MMG & MRI és MMG \\
\hline $50-59$ & Esetleg MMG & MMG & $\begin{array}{l}\text { MMG vagy MRI } \\
\text { denz emlő esetén }\end{array}$ \\
\hline $60-69$ & MMG & MMG & $\begin{array}{l}\text { MMG vagy MRI } \\
\text { denz emló esetén }\end{array}$ \\
\hline
\end{tabular}

képalkotó vizsgálat kiválasztásában. Az emlő-MR-vizsgálatokat is emlőszűrő centrumokban ajánlott végezni a minőségi kontroll rendszeres ellenőrzése céljából.

Ultrahanggal végzett szűrővizsgálat általában véve nem javasolt. Ez alól kivételt képezhet esetleg, amikor az MRI-vel végzett szűrővizsgálatot nem lehet elvégezni (például claustrophobia miatt), vagy olyan speciális esetekben, amikor a mammogrammal vagy MRI-vel végzett vizsgálat értékelése nem egyértelmú [23].

Azoknak a betegeknek, akiknek az anamnézisében már szerepel korábbi emlőrák és a magas vagy nagyon magas kockázatú csoporthoz tartoznak, 50 és 69 év között ajánlott az évenkénti mammográfiás vizsgálat elvégzése. Fontos megemlíteni, hogy a kimutatott TP53mutáció-hordozókra ez nem vonatkozik, csak a BRCAmutációval rendelkezőkre. Ugyanebben a csoportban évenkénti MRI javasolt 30-49 év között. Általában véve az MRI-vel történő szürővizsgálat gyakoriságának megegyezőnek kell lennie azon egyének szürővizsgálatával, akiket emlőcarcinomával nem diagnosztizáltak. A fentiek azonban a Brit Emlőradiológiai Társaság közeljövőben megjelenő új konszenzus ajánlásai alapján módosulhatnak.

Magyarországon az örökletes emlőrák radiológiai szűrésére átfogó szakmai irányelvek nincsenek. A 2009-es 2. Emlőrák Konszenzuskonferencia csak érintőlegesen tér ki erre a kérdésre, megemlítve, hogy a veszélyeztetett személyeknek (legalább 20-25\%-os emlőrákkockázat lifetime risk - esetén) 30 éves kor felett évente javasolt a mammográfiás szưrés, kiegészítve lehetőség szerint emlő-MR-vizsgálattal vagy ultrahanggal [24]. A mindennapi gyakorlatban, ha egyértelmúen bizonyított a BRCA 1/2 génhordozás, akkor 40 éves kor felett évente ajánlott a mammográfia, denz emlők esetén kiegészítő emlőUH, és ha lehet, MR-vizsgálat is javasolt. 40 éves életkor alatt évente UH és MR-vizsgálat javasolt, 35-40 éves kor között mammográfia is ajánlott.

\section{Kemoprevenció}

Tamoxifen (vagy raloxifen) ajánlható 5 éves időtartamra kemoprevenció céljából magas vagy nagyon magas kockázatú egyéneknek [25]. Mindez független attól, hogy az adott egyén anamnézisében szerepel-e hysterectomia. Természetesen thromboembolia vagy endometriumcarcinoma kialakulására való fokozott hajlam esetében a kemoprevenció kontraindikált [26]. Közepes kockázatú egyéneknek is ajánlható a fenti kemoprevenció szükség esetén, de 5 éves időtartamon túl semmilyen esetben sem javasolható tamoxifen adása kemoprevenció céljából. A tamoxifen és a raloxifen (szelektív ösztrogénreceptor-modulátor) preventív hatását összehasonlító adatok szerint előbbi hatékonyabb, ezért a mindennapi gyakorlatban tamoxifen használatos kemoprevencióra [26]. Olyan egyéneknek, akik korábbi rizikócsökkentő mastectomián estek át, kemoprevenció ajánlása nem indokolt. 


\section{Rizikócsökkentő mastectomia és salpingo-oophorectomia}

A régebbi profilaktikus mastectomia elnevezést fokozatosan átvette a rizikócsökkentő mastectomia, mivel mastectomia után is visszamarad az emlöállomány 3-5\%-a, amelynek talaján emlőcarcinoma fejlódhet ki [27]. Habár a mastectomia nem $0 \%$-ra csökkenti az esélyét egy esetleges emlőrák kialakulásának, magas vagy nagyon magas rizikójú egyénekben mastectomia után az emlőcarcinoma kialakulásának esélye az alacsony kockázatú populáció szintje alá csökken [28] (1. táblázat).

Kétoldali mastectomiáról, mint a rizikócsökkentés egyik eszközéről, minden magas kockázatú egyénnel konzultálni kell, de összességében a magas és nagyon magas kockázatú egyének kis hányadában végzik el ezt a mútétet. Nagyon magas kockázatú, kimutatott BRCAlvagy BRCA2-mutáció esetén is a betegek körülbelül 15\%-ánál végeztünk kétoldali mastectomiát és azonnali rekonstrukciót a nyugat-skóciai klinikai genetikai adatbázis adatai alapján, ez azonban valamelyest megemelkedett a 2013-as „Angelina Jolie-effektus” óta [29]. A döntés meghozatala egy multidiszciplináris team feladata, amelynek tagja a klinikai genetikus, onkoplasztikai emlôsebész (vagy általános és plasztikai sebész), pszichológus (a mútét pszichoszociális és szexuális életre gyakorolt hatása miatt), szükség esetén emlőradiológus és onkológus [30]. Genetikai szưrővizsgálat, családi anamnézis részletes kidolgozása és ellenőrzése a rákregisztereken keresztül előfeltétele a döntés meghozatalának. A beteggel elöre konzultálni kell az azonnali és halasztott emlőrekonstrukció lehetőségeiról, illetve a mútét során felfedezett okkult emlőcarcinoma előfordulásáról és annak terápiás következményeiről. Mivel az azonnali rekonstrukció során alkalmazott bőrkímélő vagy emlóbimbómegtartó mastectomiák onkológiai biztonsága lényegében megegyező a hagyományos mastectomia onkológiai biztonságával, kézenfekvő, hogy rizikócsökkentő mastectomia esetén is elvégezzük az azonnali emlőrekonstrukciót, ami egyébként is óhaja a betegek többségének [31, 32] (1. ábra). Ugyanakkor részletes tájékoztatást kell nyújtani a mastectomia testképet befolyásoló hatásáról. A rekonstruált emlő ugyanis elkerülhetetlenül másképp fog kinézni, mint az eredeti, és a tapintása - a felhasznált lebeny konzisztenciájától függően - is eltérő lesz [33]. Tudomásul kell vennünk azonban azt is, hogy rizikócsökkentő indikációval végzett subcutan és a totális mastectomia között a klinikai eredmények tekintetében nem történt még jelentős összehasonlító vizsgálat. Azoknak a betegeknek, akik nem élnek a felajánlott rizikócsökkentő mastectomia lehetőségével, a kockázati kategóriájuknak megfelelő rendszeres szúrővizsgálatot kell ajánlani.

Rizikócsökkentő mastectomiát lehet felajánlani olyan betegeknek is, akiket korábban már diagnosztizáltak emlőcarcinomával és BRCA1-, BRCA2- vagy TP53-génmutáció-hordozók, vagy nagy valószínúséggel azok.

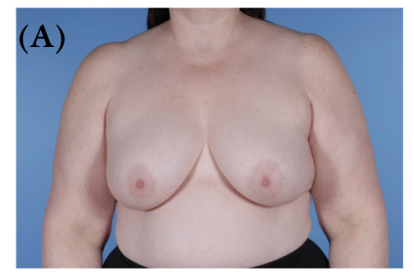

Mútét előtt

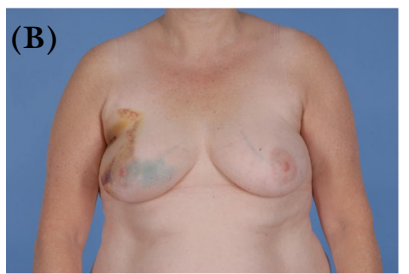

Mütét előtt

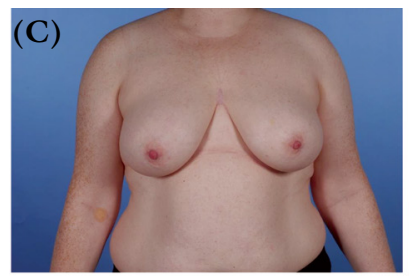

Mútét előtt

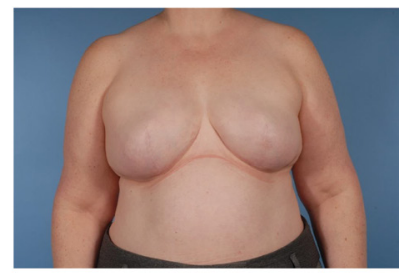

Mútét után

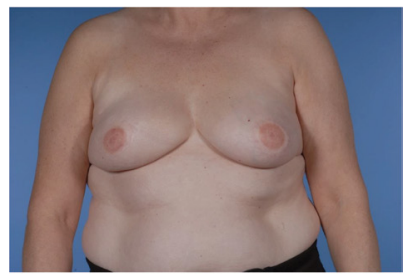

Mütét után

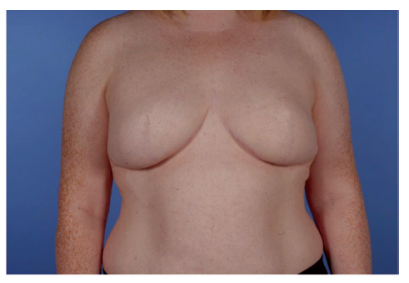

Műtét után
1. ábra $\mid$ Rizikócsökkentő kétoldali mastectomia és azonnali emlőre konstrukció implantátummal (New Victoria Hospital, Glasgow) (A), kiterjesztett latissimus dorsi lebennyel (Queen Elizabeth University Hospital, Glasgow) (B) és DIEP szabad lebennyel (Royal Infirmary, Glasgow) (C)

A fentiekhez hasonlóan itt is multidiszciplináris keretek között kell a döntést meghozni klinikai genetikus és pszichológus bevonásával. Ebben az esetben külön mérlegelendő a korábbi emlőrákból adódó distalis metasztázis és az ellenoldali emlőtumor kialakulásának valószínúsége. Következésképpen, rizikócsökkentő mútétet nem kell ajánlani azoknak a betegeknek, akiknek eleve rossz a korábbi emlőrákból eredő prognózisa. A fentiekből adódóan a mútét indikációja itt elsősorban az, hogy jelentősen csökkentheti a további primer emlőrák kialakulásával járó feszültséget a betegekben, de a korábban kialakult emlőrák prognózisán az újabb mútét már nem változtat.

Fontos megjegyezni, hogy eddig semmilyen lényeges összehasonlító vizsgálatot nem publikáltak a rizikócsökkentő mastectomia és az utánkövetés hatékonyságára. Sem a klinikai eredményeket, sem a pszichoszociális vonatkozásokat nem hasonlították össze. Mindez azért fontos, mert rizikócsökkentés indikációjával végzett mastectomia és azonnali rekonstrukció után a betegek elégedettsége a mútéttel szignifikánsan alacsonyabb (vagy elvárásuk magasabb), mint emlőrák diagnózisa miatt végzett hasonló mútét után [34].

A jelenlegi magyarországi helyzetet jellemzi, hogy kimutatott génmutáció esetén sem támogatja a társadalombiztosító a rizikócsökkentő mastectomiát és az azon- 
nali helyreállító mütétet. Ugyanakkor kimutatott génmutáció esetén nem egy intézetben elvégzik a mastectomiát és az azonnali emlőrekonstrukciót, ha ezzel egy időben vagy korábban a beteget emlőcarcinomával diagnosztizálták. A korszerü onkoplasztikai technikáknak megfelelően autológ lebennyel vagy implantátummal végzik a szövetpótlást, de utóbbinak az OEP finanszírozási rendszere ismételten határt szabhat, mivel az emlőimplantátumok támogatása is csak korlátozott mértékben valósul meg.

Kétoldali rizikócsökkentő oophorectomia (kétoldali ovarium és a petevezeték egyidejű eltávolítása) lehetőségéről is konzultálni kell minden olyan egyénnel, aki magas vagy nagyon magas kockázatú csoportba tartozik. A fenti elvek betartása mellett (multidiszciplináris döntéshozatal, genetikai szűrővizsgálat fontossága stb.) fontos konzultálni a korai menopauza következményeiról, annak kezelési lehetőségeiről, különösképpen a hormonszubsztitúció előnyeirôl és hátrányairól. Amennyiben lehetséges, ajánlatos a rizikócsökkentő salping-oophorectomiát a családtervezési ciklus utánra halasztani.

\section{Új terápiás lehetőségek az örökletes emlőrák szisztémás kezelésében}

Örökletes emlőrák esetén a szisztémás terápia irányelvei azonosak a sporadikus emlőrákok kezelési elvével. Jelenleg egyetlen irányelv sem fogalmaz meg határozottan eltérő ajánlást az örökletes emlőrákok gyógyszeres terápiájára, ugyanakkor a kutatási eredmények bővülésével, ismereteink gyarapodásával már megjelennek bizonyos javaslatok elsősorban a $B R C A$-génmutációt hordozó betegekre vonatkozóan.

A legtöbb emlődaganat, amely $B R C A$ (elsősorban $B R C A 1)$ csíravonal-mutáció következtében alakul ki, tripla negatív emlőrák (triple negative breast cancer TNBC), a génexpressziós vizsgálatok alapján „basal-like” típusú. A fentiek alapján e tumorszuppresszor gének hibája esetén a repair mechanizmus elmaradása miatt a genom instabillá válik. DNS repair mechanizmusok közül számos ismert. Míg a BRCA-gének a DNS mindkét szálának törésekor végzik el a hiba kijavítását, addig más enzimek, például a PARP (poli-ADP-ribóz polimeráz) az egyszálú DNS-törés kijavítását végzi [35]. A homológ rekombinációs DNS-javítás mechanizmusa, amit a BRCA-gén is végez, a legmegbízhatóbb DNS repair mechanizmus. A PARP gátlásával pontosan ez a homológ rekombinációs repair mechanizmus hiányában szenvedő sejteket lehet specifikusan célozni, azaz BRCA és PARP együttes „hiányában” a tumorsejt elpusztul, míg csak az egyik müködésének kiesése esetén a tumorsejt még képes fennmaradni [36]. A DNS repair mechanizmusok hibája talaján kialakult tumorok érzékenyebbek a DNS-károsító citosztatikumokra. Elsősorban a platinaszármazékokra érzékenyek a BRCA-mutáció talaján kialakult TNBC-k. Emellett a PARP-mechanizmus gátlására kifejlesztett PARP-inhibitorok (olaparib, iniparib, veliparib, nirapa- rib) alkalmazása tovább fokozhatja ezt az érzékenységet. Az elmélet bizonyítására számos klinikai vizsgálat történt, illetve zajlik jelenleg is.

Preklinikai vizsgálatokban BRCAl-deficiens MX-1 xenograft modellben a veliparib szignifikáns mértékben fokozta a carboplatin tumorellenes hatását, ugyanakkor a tumorgátló hatás veliparib-monoterápia vagy paclitaxel kombináció mellett nem volt megfigyelhető [37]. $B R C A 1$ - és/vagy $B R C A 2$-deficiens betegcsoportban a napi $2 \times 400 \mathrm{mg}$ olaparib adásával egy egykarú vizsgálatban 41\%-os válaszadási arányt lehetett elérni, ugyanakkor egy másik vizsgálatban csak csíravonal-mutációt hordozó betegekben találták hatékonynak az olaparibot [38, 39]. A veliparibot (ABT-888) temozolomiddal kombinálva egy fázis II vizsgálatban kimagaslóan hatékonynak találták $B R C A$-csíramutációt hordozókban, a válaszadási arány 37,5\% volt, 62,5\%-os klinikai előnnyel [40]. Humán vonatkozásban eddig metasztatikus emlőrákos betegek körében állnak rendelkezésre ígéretes eredmények PARP-gátlókkal, adjuváns és neoadjuváns alkalmazásukkal jelenleg is több klinikai vizsgálat zajlik $[38,40]$.

Még több ígéretes eredmény látott napvilágot az utóbbi években a platinaszármazékok (ciszplatin és carboplatin) hatékonyságáról BRCA-mutáció-asszociált emlőrákban mind metasztatikus, mind neoadjuváns körülmények között.

A platinaszármazékok aktivitását mind retrospektív, mind randomizált neoadjuváns vizsgálatok igazolják. Több vizsgálat alapján is $60 \%$ feletti komplett patológiai remissziót lehetett igazolni ciszplatin-monoterápiával [41]. A német GeparSixto vizsgálatban BRCA-mutáns vagy egyéb öröklődő tripla negatív emlőrák alcsoportban a carboplatin hozzáadása az antracyclin plusz taxán kezeléshez, szintén jelentősen növelte a komplett remisszió arányát [42]. Metasztatikus vizsgálatok közül a fázis III TNT-vizsgálat volt az első, amely nagyobb betegszám bevonásával igazolta, hogy BRCA-mutáció hordozása esetén a carboplatinkezeléssel szignifikánsan hosszabb betegségmentes túlélést lehet elérni, mint mutáció nélküli tripla negatív emlőrákban [43]. Egy másik, tripla negatív metasztatikus emlőtumoros betegek bevonásával végzett vizsgálatban, a TBCRC009 vizsgálatban pedig platina-monoterápiával $54,5 \%$-os válaszarányt lehetett kimutatni $B R C A$-mutáció mellett, míg mutáció nélkül ez csak 19,7\% volt [44]. A PARP-inhibitor, olaparib klinikai hatását BRCAl és BRCA2 talaján kialakult emlőrákban humán vizsgálat is megerősítette [38]. Jelenleg számos klinikai vizsgálatban tanulmányozzák a különböző PARP-inhibitorok esetleges jótékony hatását örökletes emlőrákban. Többek között egy III-as fázisú prospektív, multicentrikus, randomizált, placebokontrollált klinikai vizsgálatban (OlympiA; NCT02032823) tanulmányozzák oliparib hatását adjuváns terápia formájában, illetve egy másik PARP-inhibitor, a niraparib hatását metasztatikus emlőrákban (BRAVO; NCT01905592). 
Mindezeken felül örökletes ovariumrákban is folynak klinikai vizsgálatok PARP-inhibitorokkal.

Tripla negatív emlőrákokban a legismertebb, leggyakoribb receptor az EGFR/HERI receptor. Ennek ellenére, sajnos, a különféle EGFR-gátlókkal végzett fázis II klinikai vizsgálatok nem igazolták ezen mechanizmus szignifikáns terápiás előnyét sem tripla negatív, sem $B R C A$-asszociált tumoroknál $[44,45]$. Az angiogenesisgátlók közül a bevacizumab került törzskönyvezésre tripla negatív, illetve Her2-negatív metasztatikus emlőrák első vonalbeli kezelésére, ugyanakkor $B R C A$-asszociált tumorokban nem írtak le specifikusan kiemelkedő hatást angiogenesisgátlókkal.

A mindennapi gyakorlatban a $B R C A$-csíramutáció talaján kialakult emlőrák kezelése a jelenlegi irányelvek alapján megegyezik az azonos immunfenotípusú nem örökletes emlőrák kezelésével [46]. A betegek adjuváns/ neoadjuváns kezelése a kockázati besorolás alapján történik. Közepes-nagy kockázatú tripla negatív emlőrák eseteiben a standard ajánlott szisztémás adjuváns kezelés az antracyclin-taxán szekvencia [47]. Metasztatikus esetben is hasonló elveket követünk, figyelembe véve a korábbi adjuváns/neoadjuváns kezelés fajtáját, a kiújulás óta eltelt időt, a visceralis krízis jelenlétét vagy hiányát stb. Ugyanakkor a platinaszármazékokkal észlelt egyes kiemelkedő válaszadási arányok alapján valószínúleg módosulni fog ennek a relatíve ritka alcsoportnak a kezelési algoritmusa. Így például a 2015-ös St. Gallen-i konszenzuskonferencián a panel nagyobb hányada $(57,9 \%)$ támogatta a platinaalapú adjuváns kezelést BRCA-mutáció talaján kialakult TNBC esetén, mindemellett a szavazók 75\%-a az antracyclin-taxán tartalmú kezeléseket is elfogadhatónak tartja ebben a betegcsoportban [48]. Elörehaladott esetben pedig a legutóbbi ESO-ESMO nemzetközi konszenzus ajánlása tartalmazza a metasztatikus $B R C A$-asszociált tripla negatív vagy endokrin rezisztens emlődaganat esetén a platina alkalmazását, amennyiben előzetesen a beteg már kapott antracyclint és taxánt, illetve nem vesz részt klinikai vizsgálatban [49].

A korai és az előrehaladott stádiumú betegségre is érvényes, hogy a páciensek kezelését klinikai vizsgálat keretein belül érdemes megszervezni. Így tudjuk jelenleg a legoptimálisabbnak vélt kezelési szekvenciákat biztosítani, miközben magasabb szintû evidenciák birtokába jutunk, és ezáltal a jövőben még precízebb, hatékonyabb terápiás lehetőségeink lesznek e speciális figyelmet igénylő betegcsoport ellátására.

\section{Az örökletes emlőrák szürésének és megelőzésének költségei}

Jelentősen megterheli az egészségügyi költségvetést az örökletes emlőrák diagnózisa, szûrése és megelőzése. Sokkal több genetikai tesztvizsgálat és emlő radiológiai vizsgálat lesz indikált a közeljövőben. A skóciai munkacsoport számításai szerint (Familial Breast Cancer Report; NHS Scotland) mindezek egy 5 éves ciklusban kö- rülbelül 4 millió fontba fognak kerülni (a genetikai tesztek mintegy 3 millió fontba, a radiológiai vizsgálatok majdnem 900 ezer fontba, míg a tamoxifennel végzett kemoprevenció 100 ezer font feletti összeg) Skóciában, ami a populáció szempontjából a magyarországinak alig több mint a fele.

A jelenlegi magyarországi helyzettel kapcsolatban elmondható, hogy a BRCA1, BRCA2, TP53 géndiagnosztikát az Országos Egészségbiztosítási Pénztár (OEP) nem finanszírozza. Szakorvosi beutalóval és indoklással a biztosítottak számára az OEP metodikai alapon finanszírozza a BRCA-vizsgálatokat 20 éve, de a nevesített genetikai teszteket közvetlenül nem támogatja. Szűrővizsgálatként végzett mammográfia jogszabályban meghatározott, életkorhoz kötött gyakorisággal végezhetô társadalombiztosítás terhére, de betegség konkrét gyanúja esetén, a diagnózis (és nem szûrés) függvényében szakorvosi beutalóval gyakoribb vizsgálat végzése is lehetséges. Betegség gyanúja esetén támogatja a társadalombiztosítás az emlő-MRI-t is, szûrésre azonban nem. Mivel a genetikai mutáció jelenléte nem jelent bizonyított betegséget, ezért egészséges nőnél a rizikócsökkentő mastectomiát és azonnali rekonstrukciót az OEP nem finanszírozza. Hasonlóképpen nem finanszírozza a kemoprevenciót sem a társadalombiztosítás.

\section{Az ajánlások összefoglalása magas és nagyon magas kockázatú egyének esetében}

Malignitás egyidejû diagnosztizálása magas és nagyon magas familiáris kockázattal bíró betegek esetében a beteg prognózisát a már kialakult emlőrák határozza meg, de a mútéti kezelés után megmaradt emlóállomány kockázatát egyénre szabottan külön meg kell tárgyalni. Szükség esetén további rizikócsökkentő mütétet lehet felajánlani, vagy az eredeti mútéti tervet lehet módosítani, annak kiterjesztésével.

Magas és nagyon magas kockázatú egyéneknek rizikócsökkentő mútétet vagy radiológiai szúrést és - lehetőség szerint - kemoprevenciót kell felajánlani. A legtöbb beteg a radiológiai szúrést választja.

1. Rizikócsökkentő mútét esetén az azonnali emlőrekonstrukció lehetőségét fel kell ajánlani. Azonnali emlőrekonstrukció esetén a rizikócsökkentő mútétet onkoplasztikai emlősebész vagy általános sebész és plasztikai sebész együttesen végezze el! A rizikócsökkentó mútét elött klinikai pszichológus véleményét minden esetben ajánlatos kikérni.

2. Radiológiai szürés esetén a 2. táblázat irányelvei szerint általában 30 éves kor felett évenként emlő-MRI, 40 éves kor felett mammográfia és MRI évenkénti elvégzése javasolt. 50 éves kor felett az emlőállomány denzitása befolyásolhatja az MRI szükségességét.

3 . Amennyiben lehetséges, a kemoprevenció lehetőségét is fel kell ajánlani. 
Anyagi támogatás: A cikk megírása anyagi támogatásban nem részesült.

Szerzôi munkamegosztás: A szerzők a saját szakterületükön járultak hozzá az összefoglaló kézirat elkészítéséhez, felsorolásuk sorrendjével csökkenő jelentőségben.

A cikk végleges változatát valamennyi szerző elolvasta és jóváhagyta.

\section{Érdekeltségek: A szerzóknek nincsenek érdekeltségeik.}

\section{Irodalom}

[1] Familial breast cancer: classification, care and managing breast cancer and related risks in people with a family history of breast cancer (NICE guidelines [CG164]). National Institute for Health and Care Excellence. 2013. https://www.nice.org.uk/ guidance $/ \operatorname{cgl} 64$

[2] Familial Breast Cancer Report. Healthcare Improvement Scotland. 2014. http://www.healthcareimprovementscotland.org/ our_work/cancer_care_improvement/programme_resources/ familial_breast_cancer_report.aspx

[3] Van Der Looij, M., Szabo, C. Besznyak, I., et al.: Prevalence of founder BRCA1 and BRCA2 mutations among breast and ovarian cancer patients in Hungary. Int. J. Cancer, 2000, 86(5), 737-740.

[4] Antoniou, A. C., Cunningham, A. P., Peto, J., et al.: The BOADICEA model of genetic susceptibility to breast and ovarian cancers: updates and extensions. Br. J. Cancer, 2008, 98(8), 1457-1466.

[5] Phillips, K. A., Milne, R. L., Rookus, M. A., et al.: Tamoxifen and risk of contralateral breast cancer for BRCAl and BRCA2 mutation carriers. J. Clin. Oncol., 2013, 31(25), 3091-3099.

[6] Lee, J. M., Ledermann, J. A., Kohn, E. C.: PARP Inhibitors for BRCAl $/ 2$ mutation-associated and BRCA-like malignancies. Ann. Oncol., 2014, 25(1), 32-40.

[7] Evans, D. G., Lalloo, F., Hopwood, P., et al.: Surgical decisions made by 158 women with hereditary breast cancer aged $<50$ years. Eur. J. Surg. Oncol., 2005, 31(10), 1112-1128.

[8] Robson, M. E., Bradbury, A. R., Arun, B., et al.: American Society of Clinical Oncology Policy Statement Update: Genetic and genomic testing for cancer susceptibility. J. Clin. Oncol., 2015, 33(31), 3660-3667.

[9] Rosenberg, S. M., Ruddy, K. J., Tamimi, R. M., et al.: BRCAl and BRCA2 mutation testing in young women with breast cancer. JAMA Oncol., 2016, 2(6), 730-736.

[10] Orban, T. I., Olah, E.: Emerging roles of BRCAl alternative splicing. Mol. Pathol., 2003, 56(4), 191-197.

[11] Orban, T. I., Olah, E.: Expression profiles of BRCAl splice variants in asynchronous and in $\mathrm{Gl} / \mathrm{S}$ synchronized tumor cell lines. Biochem. Biophys. Res. Commun., 2001, 280(1), 32-38.

[12] Orban, T. I., Olah, E.: Purifying selection on silent sites - a constraint from splicing regulation? Trends Genet., 2001, 17(5), 252-253.

[13] Rebbeck, T. R., Mitra, N., Wan, F., et al.: Association of type and location of BRCAl and BRCA2 mutations with risk of breast and ovarian cancer. JAMA, 2015, 313(13), 1347-1361.

[14] Bojesen, S. E., Pooley, K. A., Johnatty, S. E., et al.: Multiple independent variants at the TERT locus are associated with telomere length and risks of breast and ovarian cancer. Nat. Genet., 2013 45(4), 371-384.

[15] Olah, E.: Molecular cancer genetics in eastern and central Europe. Dis. Markers, 1999, 15(1-3), 75-77.

[16] Andrieu, N., Goldgar, D. E., Easton, D. F., et al.: Pregnancies, breast-feeding, and breast cancer risk in the International
BRCAl / 2 Carrier Cohort Study (IBCCS). J. Natl. Cancer Inst., 2006, 98(8), 535-544.

[17] Antoniou, A., Pharoah, P. D., Narod, S., et al.: Average risks of breast and ovarian cancer associated with BRCAl or BRCA2 mutations detected in case series unselected for family history: a combined analysis of 22 studies. Am. J. Hum. Genet., 2003, 72(5), 1117-1130.

[18] Ramus, S. J., Kote-Jarai, Z., Friedman, L. S., et al.: Analysis of BRCAl and BRCA2 mutations in Hungarian families with breast or breast-ovarian cancer. Am. J. Hum. Genet., 1997, 60(5), 1242-1246.

[19] Olah, E.: Hereditary neoplastic diseases (genetic predisposition and cancer syndromes). [Örökletes genetikai betegségek (genetikai hajlam és daganat szindrómák).] Orv. Hetil., 1999, 140(9), 451-466. [Hungarian]

[20] Kriege, M., Brekelmans, C. T., Obdeijn, I. M., et al.: Factors affecting sensitivity and specificity of screening mammography and MRI in women with an inherited risk for breast cancer. Breast Cancer Res. Treat., 2006, 100(1), 109-119.

[21] Leach, M. O., Boggis, C. R., Dixon, A. K., et al.: Screening with magnetic resonance imaging and mammography of a UK population at high familial risk of breast cancer: a prospective multicentre cohort study (MARIBS). Lancet, 2005, 365(9473), 1769-1778.

[22] Rijnsburger, A. J., Obdeijn, I. M., Kaas, R., et al.: BRCAl-associated breast cancers present differently from BRCA2-associated and familial cases: long-term follow-up of the Dutch MRISC Screening Study. J. Clin. Oncol., 2010, 28(36), 5265-5273.

[23] Kubl, C. K., Schrading, S., Leutner, C. C., et al.: Mammography, breast ultrasound, and magnetic resonance imaging for surveillance of women at high familial risk for breast cancer. J. Clin. Oncol., 2005, 23(33), 8469-8476.

[24] Forrai, G., Szabó, E., Ormándi, K., et al.: Use of imaging methods for up-to-date diagnosis and screening of breast cancer. [A képalkotó vizsgálómódszerek alkalmazása az emlődaganatok korszerü diagnosztikájában és szűrésében.] Magy. Onkol., 2010, 54(3), 211-216. [Hungarian]

[25] Cuzick, J., Forbes, J. F., Sestak, I., et al.: Long-term results of tamoxifen prophylaxis for breast cancer - 96-month follow-up of the randomized IBIS-I trial. J. Natl. Cancer Inst., 2007, 99(4), 272-282.

[26] Vogel, V. G., Costantino, J. P., Wickerham, D. L., et al.: Update of the National Surgical Adjuvant Breast and Bowel Project Study of Tamoxifen and Raloxifene (STAR) P-2 Trial: Preventing breast cancer. Cancer Prevent. Res. (Phila.), 2010, 3(6), 696706.

[27] Romics, L. Jr., Chew, B. K., Weiler-Mithoff, E., et al.: Ten-year follow-up of skin-sparing mastectomy followed by immediate breast reconstruction. Br. J. Surg., 2012, 99(6), 799-806.

[28] Meijers-Heijboer, H., van Geel, B., van Putten, W. L., et al.: Breast cancer after prophylactic bilateral mastectomy in women with a BRCAl or BRCA2 mutation. N. Engl. J. Med., 2001, 345(3), 159-164.

[29] Evans, D. G., Barwell, J., Eccles, D. M., et al.: The Angelina Jolie effect: how high celebrity profile can have a major impact on provision of cancer related services. Breast Cancer Res., 2014, $16(5), 442$.

[30] Hopwood, P., Lee, A., Shenton, A., et al.: Clinical follow-up after bilateral risk reducing ('prophylactic') mastectomy: mental health and body image outcomes. Psychooncology, 2000, 9(6), $462-472$.

[31] Khan, J., Barrett, S., Forte, C., et al.: Oncoplastic breast conservation does not lead to a delay in the commencement of adjuvant chemotherapy in breast cancer patients. Eur. J. Surg. Oncol., 2013, 39(8), 887-891.

[32] Mátrai, Z., Gulyás, G., Tóth, L., et al.: The place of skin-sparing mastectomy in oncoplastic breast surgery. [A börtakarékos mas- 
tectomia helye a modern onkoplasztikai emlősebésztben.] Magy. Onkol., 2011, 55(4), 252-267. [Hungarian]

[33] Mátrai, Z., Gulyás, G., Tóth, L., et al.: Oncoplastic challenges in modern breast surgery. [A modern emlősebészet onkoplasztikai kihívásai.] Magy. Onkol., 2011, 55(1), 40-52. [Hungarian]

[34] Lloyd, S. M., Watson, M., Oaker, G., et al.: Understanding the experience of prophylactic bilateral mastectomy: a qualitative study of ten women. Psychooncology, 2000, 9(6), 473-485.

[35] Sonnenblick, A., de Azambuja, E., Azim, H. A. Jr., et al.: An update on PARP inhibitors - moving to the adjuvant setting. Nat. Rev. Clin. Oncol., 2015, 12(1), 27-41.

[36] Lord, C. J., Ashworth, A.: Mechanisms of resistance to therapies targeting BRCA-mutant cancers. Nat. Med., 2013, 19(11), 1381-1388

[37] Weil, M. K., Chen, A. P.: PARP inhibitor treatment in ovarian and breast cancer. Curr. Problems Cancer, 2011, 35(1), 7-50.

[38] Tutt, A., Robson, M., Garber, J. E., et al.: Oral poly(ADP-ribose) polymerase inhibitor olaparib in patients with $\mathrm{BRCAl}$ or BRCA2 mutations and advanced breast cancer: a proof-of-concept trial. Lancet, 2010, 376(9737), 235-244.

[39] Gelmon, K. A., Hirte, H. W., Robidoux, A., et al.: Can we define tumors that will respond to PARP inhibitors? A phase II correlative study of olaparib in advanced serous ovarian cancer and triple-negative breast cancer. J. Clin. Oncol., 2010, 28(15 Suppl.), Abstr. 3002.

[40] Isakoff, S. J., Overmoyer, B., Tung, N. M., et al.: A phase II trial of the PARP inhibitor veliparib (ABT888) and temozolomide for metastatic breast cancer. J. Clin. Oncol., 2010, 28(15 Suppl.), Abstr. 1019.

[41] Byrski, T., Huzarski, T., Dent, R., et al.: Pathologic complete response to neoadjuvant cisplatin in BRCAl-positive breast cancer patients. Breast Cancer Res. Treat., 2014, 147(2), 401-405.

[42] Von Minckwitz, G., Schneeweiss, A., Loibl, S., et al.: Neoadjuvant carboplatin in patients with triple-negative and HER2-positive early breast cancer (GeparSixto; GBG 66): a randomised phase 2 trial. Lancet Oncol., 2014, 15(7), 747-756.

[43] Tutt, A., Ellis, P., Kilburn, L., et al.: The TNT trial: A randomized phase III trial of carboplatin (C) compared with docetaxel (D) for patients with metastatic or recurrent locally advanced triple negative or $\mathrm{BRCAl} / 2$ breast cancer (CRUK/ 07/012). Cancer Res., 2015, 75(9 Suppl.), Abstr. S3-01.

[44] Isakoff, S. J., Mayer, E. L., He, L., et al.: TBCRC009: A multicenter phase II clinical trial of platinum monotherapy with biomarker assessment in metastatic triple-negative breast cancer. J. Clin. Oncol., 2015, 33(17), 1902-1909.

[45] Baselga, J., Gomez, P., Awada, A., et al.: The addition of cetuximab to cisplatin increases overall response rate (ORR) and progression-free survival (PFS) in metastatic triple-negative breast cancer (TNBC): results of a randomized phase II study (BALI-1). Ann. Oncol., 2010, 21(8S), Abstr. 2740.

[46] Kocsis, J., Béres, E., Horváth, Zs.: Up-to-date treatment of metastatic breast cancer. [A metasztatikus emlórák korszerú kezelése.] Klin. Onkol., 2015, 2(4), 223-229. [Hungarian]

[47] Stover, D. G., Winer, E. P.: Tailoring adjuvant chemotherapy regimens for patients with triple negative breast cancer. Breast, 2015, 24(Suppl. 2), S132-S135.

[48] Gnant, M., Thomssen, C., Harbeck, N.: St. Gallen/Vienna 2015: A brief summary of the consensus discussion. Breast Care (Basel), 2015, 10(2), 124-130.

[49] Cardoso, F., Costa, A., Norton, L., et al.: ESO-ESMO 2nd international consensus guidelines for advanced breast cancer (ABC2). Breast, 2014, 23(5), 489-502.

(Romics László dr., Department of Surgery, New Victoria Hospital, Grange Road, Glasgow G42 9LF, UK e-mail: Laszlo.Romics@glasgow.ac.uk

Az Orvosi Hetilap 2016, 157, 920. oldalán (23. szám) megjelent OH-Kvízre egy helyes megfejtés érkezett.

A beküldő: Dr. Bíró László.

A nyertesnek szívből gratulálunk.

A nyereményét - egy, az Akadémiai Kiadó webáruházában

kedvezményes vásárlásra jogosító kupont - e-mailen küldjük el. 